\title{
State-of-the-Art Overview of the Pharmacological Treatment of Non-Alcoholic Steatohepatitis
}

\author{
Yongin Cho ${ }^{1}$, Yong-ho Lee ${ }^{2,3,4}$ \\ ${ }^{1}$ Department of Endocrinology and Metabolism, Inha University College of Medicine, Incheon; ${ }^{2}$ Department of Internal \\ Medicine, ${ }^{3}$ Institute of Endocrine Research, Yonsei University College of Medicine; ${ }^{4}$ Department of Systems Biology, \\ Glycosylation Network Research Center, Yonsei University, Seoul, Korea
}

Non-alcoholic fatty liver disease (NAFLD) is the most common cause of chronic liver disease worldwide, and non-alcoholic steatohepatitis (NASH), a subtype of NAFLD, can progress to cirrhosis, hepatocellular carcinoma, and death. Nevertheless, the current treatment for NAFLD/NASH is limited to lifestyle modifications, and no drugs are currently officially approved as treatments for NASH. Many global pharmaceutical companies are pursuing the development of medications for the treatment of NASH, and results from phase 2 and 3 clinical trials have been published in recent years. Here, we review data from these recent clinical trials and reports on the efficacy of newly developed antidiabetic drugs in NASH treatment.

Keywords: Non-alcoholic fatty liver disease; Therapeutics; Clinical trial; Review

\section{INTRODUCTION}

Non-alcoholic fatty liver disease (NAFLD) is considered a liver manifestation of ectopic fat accumulation that is primarily caused by abdominal obesity and insulin resistance. Dysfunctional adipose tissue and increased lipolysis contribute to the development of insulin resistance and lipotoxicity in multiple organs [1]. Large amounts of free fatty acids (FFAs) from the visceral fat and dietary lipids enter the liver, and NAFLD is associated with decreased lipid excretion, increased accumulation of toxic lipids such as diacylglycerol, which induces hepatic insulin resistance, and oxidative stress. These can activate inflammatory and fibrogenic responses in multiple immune cells and hepatic stellate cells, leading to the progression of nonalcoholic steatohepatitis (NASH) $[2,3]$.

Received: 17 January 2022, Revised: 27 January 2022,

Accepted: 31 January 2022

Corresponding author: Yong-ho Lee

Division of Endocrinology and Metabolism, Department of Internal Medicine, Yonsei University College of Medicine, 50-1 Yonsei-ro, Seodaemun-gu, Seoul 03722, Korea

Tel: +82-2-2228-1943, Fax: +82-2-393-6884, E-mail: YHOLEE@yuhs.ac
The prevalence of NAFLD has increased concomitantly with increasing obesity rates. The incidence of NAFLD in the general population is about $25 \%$, but increases to more than $90 \%$ in highly obese populations $[3,4]$. NAFLD is the most common cause of chronic liver disease in the world and NASH, a subtype of NAFLD, can progress to cirrhosis, hepatocellular carcinoma, and death [4]. Recent evidence also suggests that NASH should be considered an independent cardiovascular risk factor [5].

Nonetheless, the current treatment of NAFLD or NASH is limited to lifestyle modifications, as no drugs have been officially approved by the U.S. Food and Drug Administration (FDA) for NASH treatment. In several NAFLD treatment guidelines, all drugs currently used in NAFLD treatment are considered off-label treatments [6]. Vitamin E (an antioxidant)

Copyright $(\odot 2) 22$ Korean Endocrine Society

This is an Open Access article distributed under the terms of the Creative Commons Attribution Non-Commercial License (https://creativecommons.org/ licenses/by-nc/4.0/) which permits unrestricted non-commercial use, distribution, and reproduction in any medium, provided the original work is properly cited. 
and pioglitazone (an antidiabetic agent) have been reported to be effective in improving NASH in randomized clinical trials, including the PIVENS trial [7]. However, the long-term safety of vitamin $\mathrm{E}$ is controversial due to its potential risk for increased mortality [8], and pioglitazone can increase body weight and fluid retention. Therefore, many global pharmaceutical companies are pursuing the development of medications for NASH treatment, and the results of phase 2 and 3 clinical trials have been published in recent years. Here, we review these recent clinical trial data and reports of the efficacy of newly developed antidiabetic drugs on NASH. A summary of recent clinical data is provided in Table 1 .

\section{TARGETING BILE ACID RECEPTORS/ FARNESOID X RECEPTOR}

Bile acids are natural ligands of the farnesoid X receptor (FXR) [9]. Together they regulate lipid and/or glucose homeostasis,

Table 1. Recent Clinical Trial Data of NASH Therapeutics

\begin{tabular}{|c|c|c|c|c|c|}
\hline Study author/design & Mechanism & $\begin{array}{l}\text { Intervention/ } \\
\text { controlduration }\end{array}$ & Study population & Primary endpoint & Results \\
\hline $\begin{array}{l}\text { REGENERATE trial } \\
\text { [12] } \\
\text { Phase } 3 \text { multicenter, } \\
\text { randomized, } \\
\text { double-blind, } \\
\text { placebo-controlled }\end{array}$ & A: FXR agor & $\begin{array}{l}\text { 1:1:1 } \\
\text { OCA } 25 \mathrm{mg} \\
\text { OCA } 10 \mathrm{mg} \\
\text { Placebo } \\
18 \text { months }\end{array}$ & $\begin{array}{l}\text { NASH }(\text { NAS } \geq 4), \\
\text { F1-F3 }\end{array}$ & $\begin{array}{l}\text { Fibrosis } \\
\text { improvement ( } \geq 1 \\
\text { stage) with no } \\
\text { worsening of } \\
\text { NASH, or NASH } \\
\text { resolution with no } \\
\text { worsening of } \\
\text { fibrosis }\end{array}$ & $\begin{array}{l}\text { Improved: } \\
\text { One stage in liver } \\
\text { fibrosis in OCA } 25 \\
\text { mg compared to } \\
\text { placebo }(23 \% \text { vs. } \\
12 \%, P=0.0002) \\
\text { Not improved: } \\
\text { NASH resolution }\end{array}$ \\
\hline
\end{tabular}

\begin{tabular}{|c|c|c|c|c|c|c|}
\hline $\begin{array}{l}\text { Patel et al. [14] } \\
\text { Phase } 2 \text { multinational, } \\
\text { randomized, } \\
\text { double-blind, } \\
\text { placebo-controlled }\end{array}$ & $\begin{array}{l}\text { Cilofexor: FXR } \\
\text { agonist (synthetic } \\
\text { non-steroidal) }\end{array}$ & $\begin{array}{l}2: 2: 1 \\
\text { Cilofexor } 100 \mathrm{mg} \\
\text { Cilofexor } 30 \mathrm{mg} \\
\text { Placebo } \\
6 \text { months ( } 24 \text { weeks) }\end{array}$ & $\begin{array}{l}\text { Noncirrhotic } \\
\text { NASH (MRI- } \\
\text { PDFF } \geq 8 \% \text { ), } \\
\text { liver stiffness } \\
\geq 2.5 \mathrm{kPa} \\
\text { (MRE) or } \\
\text { historical liver } \\
\text { biopsy }\end{array}$ & $\begin{array}{l}\text { The safety and } \\
\text { tolerability of } \\
\text { cilofexor }\end{array}$ & $\begin{array}{l}\text { Improved: } \\
\text { Hepatic steatosis (me- } \\
\text { dian relative de- } \\
\text { crease in MRI-PDFF } \\
\text { of }-22.7 \% \text { in the } \\
\text { cilofexor } 100 \mathrm{mg} \\
\text { group, compared } \\
\text { with an increase of } \\
1.9 \% \text { in the placebo } \\
\text { group; } P=0.003 \text { ) } \\
\text { Not improved: } \\
\text { Fibrosis (ELF, MRE, } \\
\text { CK18) }\end{array}$ & $\begin{array}{l}\text { Safety } \\
\text { Pruritis (moderate } \\
\text { to severe pruritus } \\
\text { in } 14 \% \text { of } \\
\text { patients) }\end{array}$ \\
\hline $\begin{array}{l}\text { ARGON-1 trial [18] } \\
\text { Phase } 2 \text { multinational, } \\
\text { randomized, } \\
\text { double-blind, } \\
\text { placebo-controlled }\end{array}$ & $\begin{array}{l}\text { EDP-305: FXR } \\
\text { agonist (synthetic } \\
\text { non-steroidal) }\end{array}$ & $\begin{array}{l}\text { 2:2:1 } \\
\text { EDP-305 } 2.5 \mathrm{mg} \\
\text { EDP-305 } 1 \mathrm{mg} \\
\text { Placebo } \\
3 \text { months (12 weeks) }\end{array}$ & $\begin{array}{l}\text { Non-cirrhotic/ } \\
\text { fibrotic NASH (by } \\
\text { historical biopsy } \\
\text { or phenotypically, } \\
\text { and elevated ALT } \\
\text { with LFC by } \\
\text { MRI-PDFF } \\
>8 \% \text { ) }\end{array}$ & $\begin{array}{l}\text { Mean change from } \\
\text { baseline to week } \\
12 \text { for ALT }\end{array}$ & $\begin{array}{l}\text { Improved: } \\
\text { ALT reduction } \\
\begin{array}{l}(2.5 \mathrm{mg} \text { of EDP-305: } \\
-27.9 \mathrm{U} / \mathrm{L} \\
{[P=0.049],} \\
\text { compared to }-15.4 \\
\text { U/L for those } \\
\text { receiving placebo }) \\
\text { Absolute liver fat } \\
\text { reduction of }-7.1 \% \\
(P=0.0009) \text { with } 2.5 \\
\text { mg of EDP-305 }\end{array}\end{array}$ & $\begin{array}{l}\text { Safety } \\
\text { Pruritus ( } 50.9 \% \text { in } \\
\text { the } 2.5 \mathrm{mg} \text { of } \\
\text { EDP-305 group) }\end{array}$ \\
\hline
\end{tabular}




\begin{tabular}{|c|c|c|c|c|c|c|}
\hline Study author/design & Mechanism & $\begin{array}{l}\text { Intervention/ } \\
\text { controlduration }\end{array}$ & Study population & Primary endpoint & Results & Other issues \\
\hline $\begin{array}{l}\text { 1. MAESTRO- } \\
\text { NASH study [22] } \\
\text { 2. MAESTRO- } \\
\text { NAFLD1 study } \\
\text { [23] } \\
\text { 3. MAESTRO- } \\
\text { NAFLD-Open- } \\
\text { Label-Extension } \\
\text { (MAESTRO- } \\
\text { NAFLD-OLE) } \\
\text { study [24] }\end{array}$ & $\begin{array}{l}\text { All (1-3) } \\
\text { Resmetirom } \\
\text { (MGL-3196): } \\
\text { THR } \beta \text { agonist }\end{array}$ & $\begin{array}{l}\text { All (1-3) } \\
\text { Resmetirom } 80 \mathrm{mg} \\
\text { or } 100 \mathrm{mg} \text {, } \\
\text { placebo1 } 2 \text { months } \\
\text { (52 weeks) }\end{array}$ & $\begin{array}{l}\text { 1. Biopsy-proven } \\
\text { NASH (F2-F3) } \\
\text { 2. NASH or } \\
\text { NAFLD (on } \\
\text { fibroscan/MRE } \\
\text { and MRI-PDFF/ } \\
\text { liver biopsy) } \\
\text { 3. Same as } 2\end{array}$ & $\begin{array}{l}\text { 1. NASH resolution } \\
\text { at repeated biopsy } \\
\text { 2. The incidence of } \\
\text { adverse events } \\
\text { 3. The incidence of } \\
\text { adverse events }\end{array}$ & $\begin{array}{l}\text { Recruiting } \\
\text { 1. Phase 3, multinational, } \\
\text { randomized, } \\
\text { double-blind, placebo- } \\
\text { controlled } \\
\text { 2. Phase 3, randomized, } \\
\text { double-blind, } \\
\text { placebo-controlled/ } \\
\text { Some, open-label } \\
\text { 3. Phase 3, open-label } \\
\text { extension, } \\
\text { single-blind lead-in }\end{array}$ & Recruiting \\
\hline $\begin{array}{l}\text { ARMOR trial [28] } \\
\text { Phase } 3 \text { multinational, } \\
\text { multicenter } \\
\text { 1. Double-blind, } \\
\text { part-randomized } \\
\text { 2. Open label part }\end{array}$ & $\begin{array}{l}\text { Aramchol: SCD-1 } \\
\text { inhibitor }\end{array}$ & $\begin{array}{l}\text { 1. 2:1 } \\
\text { Aramchol } 600 \mathrm{mg} \\
\text { Placebo } \\
18 \text { months ( } 72 \\
\text { weeks) } \\
\text { 2. Aramchol } 600 \mathrm{mg} \\
18 \text { or } 30 \text { months } \\
\text { (72 or } 120 \\
\text { weeks) }\end{array}$ & $\begin{array}{l}\text { Biopsy-proven } \\
\text { NASH, F2-F3 } \\
\text { (with overweight } \\
\text { or obesity, and } \\
\text { having prediabetes } \\
\text { or type } 2 \text { diabetes) }\end{array}$ & $\begin{array}{l}\text { 1. Resolution of } \\
\text { NASH and no } \\
\text { worsening of liver } \\
\text { fibrosis } \\
\text { Improvement in } \\
\text { fibrosis and no } \\
\text { worsening of } \\
\text { steatohepatitis } \\
\text { 2. Resolution of } \\
\text { NASH and } \\
\text { improvement of } \\
\text { fibrosis }\end{array}$ & Recruiting & Recruiting \\
\hline $\begin{array}{l}\text { RESOLVE-IT [33] } \\
\text { Phase } 3 \text { randomized, } \\
\text { placebo-controlled }\end{array}$ & $\begin{array}{l}\text { Elafibranor: dual } \\
\text { PPAR } \alpha / \delta \text { agonist }\end{array}$ & $\begin{array}{l}2: 1 \\
\quad \text { Elafibranor } \\
\text { Placebo } \\
\text { 18 months ( } 72 \\
\text { weeks) }\end{array}$ & $\begin{array}{l}\text { Biopsy-proven } \\
\text { NASH, F2-F3 }\end{array}$ & $\begin{array}{l}\text { NASH resolution } \\
\text { without worsening } \\
\text { of fibrosis }\end{array}$ & $\begin{array}{l}\text { Not improved: } \\
\text { Primary endpoint: } \\
(19.2 \% \text { in the } \\
\text { elafibranor arm, } \\
14.7 \% \text { in the placebo } \\
\text { arm) }\end{array}$ & $\begin{array}{l}\text { Terminated without } \\
\text { significant benefit }\end{array}$ \\
\hline $\begin{array}{l}\text { EVIDENCES IV } \\
\text { study [34] } \\
\text { Phase } 2 \text { multicenter, } \\
\text { randomized, dou- } \\
\text { ble-blind, placebo- } \\
\text { controlled }\end{array}$ & $\begin{array}{l}\text { Saroglitazar: dual } \\
\text { PPAR } \alpha / \gamma \text { agonist }\end{array}$ & $\begin{array}{l}\text { 1:1:1:1 } \\
\text { Saroglitazar } 4 \mathrm{mg} \\
\text { Saroglitazar } 2 \mathrm{mg} \\
\text { Saroglitazar } 1 \mathrm{mg} \\
\text { Placebo } \\
4 \text { months (16 weeks) }\end{array}$ & $\begin{array}{l}\text { NAFLD/NASH } \\
\text { patients (by US, } \\
\text { CT, MRI, or } \\
\text { biopsy) (with } \\
\text { BMI over } \\
25 \mathrm{~kg} / \mathrm{m}^{2} \text { ) }\end{array}$ & $\begin{array}{l}\text { The percentage } \\
\text { change from } \\
\text { baseline in ALT } \\
\text { levels }\end{array}$ & $\begin{array}{l}\text { Improved: } \\
\text { ALT (in saroglitazar } \\
4 \mathrm{mg} \text {, the percentage } \\
\text { change from baseline } \\
-45.8 \% \text { ) } \\
\text { LFC (in saroglitazar } \\
4 \text { mg by MRI-PDFF, } \\
-19.7 \% \text { ) }\end{array}$ & \\
\hline $\begin{array}{l}\text { NATIVE trial [35] } \\
\text { Phase 2b double- } \\
\text { blind, randomized, } \\
\text { placebo-controlled }\end{array}$ & $\begin{array}{l}\text { Lanifibranor: pan- } \\
\text { PPAR agonist }\end{array}$ & $\begin{array}{l}\text { 1:1:1 } \\
\text { Lanifibranor } \\
1,200 \mathrm{mg} \\
\text { Lanifibranor } \\
800 \mathrm{mg} \\
\text { Placebo } \\
6 \text { months (24 weeks) }\end{array}$ & $\begin{array}{l}\text { Noncirrhotic, } \\
\text { highly active } \\
\text { NASH } \\
\text { (biopsy-proven) }\end{array}$ & $\begin{array}{l}\text { Decrease of at least } \\
2 \text { points in the } \\
\text { SAF-A score } \\
\text { without worsening } \\
\text { of fibrosis }\end{array}$ & $\begin{array}{l}\text { Improved: } \\
\text { Achieved } \\
\text { primary endpoint } \\
(1,200 \mathrm{mg} \text { vs. placebo, } \\
55 \% \text { vs. } 33 \% \\
P=0.007)\end{array}$ & \\
\hline $\begin{array}{l}\text { AURORA trial [39] } \\
\text { Phase } 3 \text { two-part } \\
\text { international, } \\
\text { randomized, } \\
\text { double-blind, } \\
\text { placebo-controlled }\end{array}$ & $\begin{array}{l}\text { Cenicriviroc: } \mathrm{C} \\
\text { motif chemokine } \\
\text { receptor type } 2 \\
\text { and } 5 \text { antagonist }\end{array}$ & $\begin{array}{l}\text { Cenicriviroc } 150 \mathrm{mg} \\
\text { Placebo } \\
12 \text { months }\end{array}$ & $\begin{array}{l}\text { Biopsy-proven } \\
\text { NASH (NAS } \\
\geq 4 \text { ), F2-F3 }\end{array}$ & $\begin{array}{l}\text { Improvement of } \\
\text { fibrosis by } \geq 1 \\
\text { grade without } \\
\text { exacerbation of } \\
\text { steatohepatitis }\end{array}$ & $\begin{array}{l}\text { Terminated early due to } \\
\text { lack of efficacy based } \\
\text { on the results of part I } \\
\text { of the AURORA study }\end{array}$ & $\begin{array}{r}\text { Terminated without } \\
\text { significant benefit }\end{array}$ \\
\hline
\end{tabular}

(Continued to the next page) 


\begin{tabular}{|c|c|c|c|c|c|c|}
\hline Study author/design & Mechanism & $\begin{array}{l}\text { Intervention/ } \\
\text { controlduration }\end{array}$ & Study population & Primary endpoint & Results & Other issues \\
\hline $\begin{array}{l}\text { EMMINENCE trial } \\
\text { [40] } \\
\text { Phase } 2 \text { b random- } \\
\text { ized, double-blind, } \\
\text { placebo-controlled }\end{array}$ & $\begin{array}{l}\text { MSDC-0602K: } \\
\text { Second- } \\
\text { generation } \\
\text { thiazolidinediones } \\
\text { - minimize direct } \\
\text { binding to PPAR } \gamma \\
\text { and preferentially } \\
\text { target the } \\
\text { mitochondrial } \\
\text { pyruvate } \\
\text { transporter }\end{array}$ & $\begin{array}{l}1: 1: 1: 1 \\
\text { MSDC-0602K } \\
250 \mathrm{mg} \\
\text { MSDC-0602K } \\
125 \mathrm{mg} \\
\text { MSDC-0602K } \\
62.5 \mathrm{mg} \\
\text { Placebo } \\
12 \text { months } \\
\text { (52 weeks) }\end{array}$ & $\begin{array}{l}\text { Biopsy-proven } \\
\text { NASH, F1-F3 }\end{array}$ & $\begin{array}{l}\geq 2 \text {-point } \\
\text { histological } \\
\text { improvement of } \\
\text { the liver on the } \\
\text { NAS, } \geq 1 \text {-point } \\
\text { decrease in } \\
\text { balloon or lobular } \\
\text { inflammation, no } \\
\text { increase in the } \\
\text { fibrosis stage }\end{array}$ & $\begin{array}{l}\text { Improved: } \\
\text { Fasting glucose, insulin, } \\
\text { glycated hemoglobin, } \\
\text { and markers of liver } \\
\text { injury } \\
\text { Not improved: Primary } \\
\text { endpoint }(29.7 \%, 29.8 \\
\%, 32.9 \% \text {, and } 39.5 \% \\
\text { of patients in the } \\
\text { placebo group, MS- } \\
\text { DC-0602K } 62.5,125 \text {, } \\
\text { and } 250 \text { mg) } \\
\text { Secondary liver } \\
\text { histology endpoints }\end{array}$ & $\begin{array}{l}\text { The incidence of } \\
\text { PPAR } \gamma \text { agonist- } \\
\text { related events such } \\
\text { as hypoglycemia, } \\
\text { edema and } \\
\text { fractures was not } \\
\text { increased. }\end{array}$ \\
\hline
\end{tabular}

NASH, non-alcoholic steatohepatitis; OCA, obeticholic acid; FXR, farnesoid X receptor; NAS, nonalcoholic fatty liver disease activity score; LDL, lowdensity lipoprotein; MRI-PDFF, magnetic resonance imaging proton density fat fraction; MRE, magnetic resonance elastography; ELF, enhanced liver fibrosis; CK, cytokeratin; LFC, liver fat content; ALT, alanine aminotransferase; NAFLD, non-alcoholic fatty liver disease; THR, thyroid hormone receptor; SCD, stearoyl-CoA desaturase; PPAR, peroxisome proliferator activated receptor; US, ultrasonography; CT, computed tomography; BMI, body mass index.

promote insulin sensitivity, and potentially regulate liver fibrosis [10]. FXR agonists have been shown to prevent the development of NASH and promote the resolution of NASH and fibrosis in rodent models [11]. Multiple FXR agonists are now being tested for NASH treatment.

\section{Obeticholic acid}

The phase 3 REGENERATE trial (NCT02548351) evaluated histological response after 18 months of maintenance in 1,968 patients who received obeticholic acid (OCA; 10 or $25 \mathrm{mg}$ ) or placebo. The results demonstrated significantly more frequent improvement by $\geq 1$ stage in liver fibrosis among patients receiving $25 \mathrm{mg}$ of OCA daily compared to patients receiving placebo ( $23 \%$ vs. $12 \%, P=0.0002)$ [12]. However, treatment with OCA also raised concerns about several adverse events. OCA at a dose of $25 \mathrm{mg}$ /day was associated with pruritus in $51 \%$ of patients. An increase in low-density lipoprotein (LDL) cholesterol levels of up to $23.8 \mathrm{mg} / \mathrm{dL}$ was observed after 1 month of OCA treatment at $25 \mathrm{mg} /$ day, which led to statin treatment in a large number of patients. More patients (3\%) who received $25 \mathrm{mg}$ of OCA experienced hepatobiliary events (gallstones or cholecystitis) than those $(<1 \%)$ who received placebo [12]. The FDA announced that the predicted benefit of OCA remains uncertain and does not sufficiently outweigh the potential risks to support accelerated approval for NASH treatment [13].
It will be necessary to confirm additional post-interim analysis efficacy and safety data from the ongoing REGENERATE study results.

Synthetic non-steroidal FXR agonists, including cilofexor [14], tropifexor [15], EDP-305 [16], and MET-409 [17] are in development, and phase 2 trials are ongoing. However, these compounds also show dose-dependent associations with pruritus. The similarity of their chemical structures to the steroid bile acid of OCA can contribute to the risk of the above drug adverse events.

\section{Cilofexor}

In a phase 2 trial, 140 patients with noncirrhotic NASH were randomized to receive cilofexor ( $30 \mathrm{or} 100 \mathrm{mg}$ ) or placebo for 24 weeks [14]. Cilofexor was well-tolerated and provided significant reductions in hepatic steatosis (median relative decrease in magnetic resonance imaging proton density fat fraction [MRI-PDFF] of $-22.7 \%$ in those receiving $100 \mathrm{mg}$ of cilofexor compared with an increase of $1.9 \%$ in those receiving placebo) [14]. Cilofexor at a dose of $100 \mathrm{mg}$ was associated with moderate to severe pruritus in $14 \%$ of patients $(4 \%$ in the placebo group).

\section{EDP-305}

In an early phase 2 study of 134 non-cirrhotic patients with fi- 
brotic NASH (ARGON-1), the primary endpoint was the mean change in alanine aminotransferase (ALT) levels from baseline to week 12, and the key secondary endpoint was the mean change in liver fat content (LFC) measured by MRI-PDFF. EDP-305 at a dose of $2.5 \mathrm{mg}$ reduced ALT levels (-27.9 U/L, $P=0.049)$ and liver fat $(-7.1 \%, P=0.0009)$. However, pruritus occurred in $50.9 \%$ of patients in the $2.5 \mathrm{mg}$ group [18].

\section{TARGETING LIVER-SPECIFIC THYROID HORMONE RECEPTORS}

Thyroid hormones are involved in the regulation of hepatic triglyceride and cholesterol metabolism [19]. Thyroid hormones reduce serum cholesterol by affecting cholesterol synthesis, LDL clearance, and reverse cholesterol transport. In this respect, thyroid hormone receptor- $\beta$ (THR- $\beta$ ), which is mainly expressed in the liver, could be a target for NAFLD treatment [19]. Currently, resmetirom and VK2809 [20] are the THR agonists that mainly act on THR- $\beta$ and are being developed for the treatment of NASH.

\section{Resmetirom}

When assessed by MRI-PDFF in a phase 2 trial, resmetiromtreated patients showed a relative reduction of hepatic fat compared with those who received placebo at week $36(-37.3 \%$ for resmetirom vs. $-8.5 \%$ for placebo, $P<0.001$ ) [21]. There was no significant difference in the proportion of patients with a $\geq$ 1-point reduction in fibrosis without worsening of the NAFLD activity score (NAS). Multiple atherogenic lipids and lipoproteins were also significantly reduced in patients who received resmetirom compared with placebo, particularly LDL cholesterol, apolipoprotein B, and triglycerides. The most common adverse effects were transient mild diarrhea and nausea [21]. There are three ongoing phase 3 trials with resmetirom [22-24]. The A Phase 3 Study to Evaluate the Efficacy and Safety of MGL-3196 (Resmetirom) in Patients With NASH and Fibrosis (MAESTRO-NASH) study is focusing on patients with biopsyproven NASH (fibrosis stages 2 and 3 [F2-F3]), and its primary endpoint is NASH resolution at a repeated biopsy after 52 weeks of treatment [22].

\section{TARGETING DE NOVO LIPOGENESIS}

Increased de novo lipogenesis is one of the distinguishing features of NAFLD. This indicates that lipogenesis can be a therapeutic target for NAFLD.

\section{Aramchol}

Arachidyl amido cholanoic acid (Aramchol) downregulates stearoyl-CoA desaturase 1 (SCD-1), a key enzyme involved in hepatic lipogenesis [25]. By inhibiting SCD-1 activity, Aramchol downregulated the production of hepatic fatty acids and reduced fibrosis in mice [26]. The ARREST trial is a phase $2 \mathrm{~b}$ trial evaluating the use of Aramchol (400 and $600 \mathrm{mg}$ ) in NASH patients with a body mass index of 25 to $40 \mathrm{~kg} / \mathrm{m}^{2}$, corresponding to overweight or obesity, as well as prediabetes or type 2 diabetes mellitus (T2DM). Improvements in liver fat measured by magnetic resonance spectroscopy (MRS) were only significant in the group receiving $400 \mathrm{mg}$ of Aramchol compared to placebo; however, the arm that received $600 \mathrm{mg}$ of Aramchol had higher rates of NASH resolution. Decreases in ALT, aspartate aminotransferase, and glycated hemoglobin were also observed in the Aramchol group. The most common adverse drug reactions were urinary tract infection, headache, itching, and nausea [27]. The ARMOR trial (NCT04104321) is an ongoing phase 3/4 trial with NASH patients with fibrosis (F2-F3) to evaluate the safety and efficacy of Aramchol (600 mg). The primary endpoint is the proportion of patients with resolution of NASH without exacerbation of liver fibrosis and an improvement of stage 1 or greater in fibrosis without exacerbation of steatohepatitis [28].

\section{Firsocostat (GS-0976)}

Acetyl-coenzyme carboxylase catalyzes the rate-limiting step in de novo lipogenesis. In a phase 2 trial, the safety and efficacy of firsocostat, an inhibitor of acetyl-coenzyme A carboxylase in the liver, was evaluated. Twelve-week administration of firsocostat (20 mg) decreased hepatic steatosis, with a relative decrease of over $30 \%$ from baseline on MRI-PDFF occurring in $48 \%$ of patients $(P=0.004$ vs. placebo) and a greater median relative decrease (decrease of $29 \%$ ) than those given placebo (decrease of $8 \%, P=0.002$ ) [29]. However, in the treatment groups that received 20 or $5 \mathrm{mg}$ of firsocostat, serum triglyceride levels increased by $11 \%$ and $13 \%$, respectively, and $14 \%$ and $18 \%$ of patients, respectively, developed asymptomatic hypertriglyceri$\operatorname{demia}(>500 \mathrm{mg} / \mathrm{dL})$.

\section{TARGETING PEROXISOME PROLIFERATOR ACTIVATED RECEPTORS}

Peroxisome proliferator activated receptor- $\alpha(\operatorname{PPAR} \alpha)$ activity is associated with increased energy burning and reduced fat storage in the liver [30]. PPAR $\alpha$ upregulates a number of genes 
that play roles in fatty acid oxidation and in phospholipid remodeling, and it inhibits hepatic inflammatory processes. Hepatic PPAR $\beta / \delta$ is involved in transforming potentially toxic lipids into less toxic molecules by regulating monounsaturated fatty acid synthesis and increasing AMP-activated protein kinase activity, thereby suppressing lipogenesis and glycogen synthesis, reducing gluconeogenesis, and increasing fatty acid oxidation. PPAR $\beta / \delta$ also stimulates anti-inflammatory responses in the liver [31].

\section{Elafibranor}

Elafibranor is a dual agonist of PPAR $\alpha$ and PPAR $\delta$. In the phase 2 GOLDEN-505 trial, no statistically significant difference was observed in the primary outcome, the resolution of NASH without worsening of fibrosis [32]. In a post hoc analysis of patients with fibrosis (F2-F3), a higher rate of NASH resolution was seen in the group that received elafibranor $(120 \mathrm{mg})$ daily than in the placebo group $(19 \%$ vs. $12 \%, P=0.045)$. A phase 3 trial (RESOLVE-IT) compared the effects of treatment for 72 weeks in patients with histologically proven NASH with fibrosis (F2F3). However, no statistically significant difference was found in the proportion of patients who experienced NASH resolution without worsening of fibrosis $(19.2 \%$ in the elafibranor arm, $14.7 \%$ in the placebo arm) [33], which led to the termination of this study.

\section{Saroglitazar}

Saroglitazar is a dual PPAR $\alpha / \gamma$ agonist. In the phase 2 EVIDENCES IV study (NCT03061721), 106 NAFLD/NASH patients were randomized to receive either placebo or saroglitazar (1, 2, or $4 \mathrm{mg}$ ). Compared with placebo, $4 \mathrm{mg}$ of saroglitazar significantly improved ALT levels at 16 weeks $(3.4 \%$ vs. $-45.8 \%$ ) and LFC as determined by MRI-PDFF (4.1\% vs. $-19.7 \%)$ [34].

\section{Lanifibranor}

Lanifibranor is a pan-PPAR agonist. In the NATIVE trial (NCT03008070), a total of 247, non-cirrhotic, highly active NASH patients were randomized to receive lanifibranor (800 or $1,200 \mathrm{mg}$ ) or placebo for 24 weeks. The primary endpoint was a decrease of at least 2 points in the activity part of the Steatosis, Activity, Fibrosis scoring system, which incorporates scores for ballooning and inflammation, without worsening of fibrosis. The percentage of patients who achieved the primary endpoint was significantly higher with the 1,200-mg dose of lanifibranor than with placebo (55\% vs. $33 \%, P=0.007)$ [35].

\section{TARGETING ANTI-INFLAMMATORY SIGNALING: C MOTIF CHEMOKINE RECEPTOR 2/5}

\section{Cenicriviroc}

$\mathrm{C}$ motif chemokine receptor types 2 and 5 are both involved in the inflammatory and fibrogenic pathways [36]. Cenicriviroc binds to these chemokine receptors as a dual antagonist, and may reduce inflammation and improve NASH [37]. The CENTAUR phase 2 trial enrolled NASH patients with NAS $\geq 4$ and liver fibrosis (stages 1-3, NASH clinical research network). The primary outcome, a $\geq 2$-point improvement in NAS and no worsening of fibrosis at year 1 , was achieved in similar proportions of subjects on cenicriviroc and placebo $(P>0.05)$. However, the fibrosis endpoint (improvement in fibrosis by $\geq 1$ stage) was met in more subjects with cenicriviroc than with placebo (20\% vs. $10 \%, P=0.023$ ) [38]. A subsequent phase 3 AURORA trial in patients with NASH and fibrosis (F2-F3) was conducted to evaluate the primary endpoint of improvement in fibrosis by $\geq 1$ grade without exacerbation of steatohepatitis at 1 year. However, this study was terminated early due to lack of efficacy [39].

\section{INSULIN SENSITIZER}

\section{MSDC-0602K}

MSDC-0602K is a second-generation thiazolidinedione (TZD) designed to minimize direct binding to PPAR $\gamma$ and preferentially target the mitochondrial pyruvate transporter. In the EMMINENCE phase 2b trial (NCT0278444), patients with biopsyconfirmed NASH and fibrosis (F1-F3) were randomized to placebo or MSDC-0602K for 52 weeks. The primary endpoint was a $\geq 2$-point histological improvement of the liver on the NAS, a $\geq 1$ point decrease in balloon or lobular inflammation, and no increase in the fibrosis stage at 12 months [40]. MSDC-0602K significantly decreased fasting glucose, insulin, glycated hemoglobin, and markers of liver injury. However, the results for the primary endpoint and liver histology outcomes did not show statistically significant improvements in the MSDC-0602K group [40].

\section{OTHER PHASE 2 CLINICAL TRIALS}

\section{Belapectin, a galectin 3 inhibitor (anti-fibrotic)}

Increased levels of galectin 3 have been associated with NASH development. Belapectin, an inhibitor of galectin 3, reduced liv- 
er fibrosis in rats [41] and was well tolerated in phase 1 studies [42]. However, receiving biweekly infusions of belapectin for 1 year was not associated with a significant reduction in fibrosis compared with placebo in a phase $2 \mathrm{~b}$ study conducted in 162 patients with NASH, cirrhosis, and portal hypertension [43].

\section{Emricasan, a caspase inhibitor (apoptosis)}

Lipotoxicity activates caspases that trigger apoptosis and the production of inflammatory cytokines. However, pan-caspase inhibition with emricasan did not improve liver histology, and may have worsened fibrosis and ballooning in patients with NASH and fibrosis (F1-F3) [44].

\section{Aldafermin (NGM282), a fibroblast growth factor-19 analogue (hormone signaling)}

Fibroblast growth factor 19 (FGF-19) plays a central role in regulating bile acids and energy metabolism in the liver via FGF receptor 4 [45]. Aldafermin, an analogue of FGF19, ameliorated hepatic steatosis with a reduction of $5.0 \%$ in absolute LFC $(P=0.002)$ in a phase 2 trial of patients with NASH [46]. In the phase 2 b ALPINE $2 / 3$ clinical trial in NASH patients with fibrosis (F2-F3), aldafermin did not meet the primary endpoint of fibrosis improvement by $\geq 1$ stage with no worsening of NASH versus placebo, and the trial was terminated [47]. A phase $2 b$ ALPINE 4 study in NASH and fibrosis (F4) patients with compensated cirrhosis is still ongoing.

\section{Pegbelfermin and efruxifermin, fibroblast growth factor-21 analogues (hormone signaling)}

FGF-21 also plays a central role in regulating energy metabolism [45]. Pegbelfermin (BMS-986036) [48] and efruxifermin [49], which are FGF-21 analogues, significantly reduced the hepatic fat fraction in patients with NASH in phase 2 trials.

\section{ANTIDIABETIC DRUGS FOR NAFLD MANAGEMENT}

T2DM results from multiple organ abnormalities and various pathophysiological abnormalities. It has been linked to insulin resistance and obesity, indicating that T2DM and NAFLD have similar pathophysiological underpinnings $[2,50]$. The recently proposed term "metabolic (dysfunction)-associated fatty liver disease (MAFLD)" suggests the importance of an approach to NAFLD that recognizes the role of metabolic dysfunction in driving the pathophysiology [51]. Adipose tissue dysfunction and insulin resistance, which is the main feature of T2DM, in- crease the release of pro-inflammatory cytokines and decrease the release of anti-inflammatory adipokines [52]. These changes can directly damage the liver or act indirectly, leading to increased oxidative stress, hepatocyte damage, progression of hepatic fibrosis, and tumor development [53]. Glucotoxicity also promotes NASH and disease progression by stimulating the de novo synthesis of FFAs and ectopic fat accumulation [54]. This suggests that T2DM risk reduction and the improvement or resolution of NAFLD are closely related [55]. Most of the drugs presented below are used for the treatment of T2DM, and many clinical studies are being conducted on patients without T2DM. Therefore, there are relatively few areas of concern in terms of safety. A summary of newly developed antidiabetic medications is provided in Table 2 .

\section{ANTIDIABETIC DRUGS FOR NAFLD MANAGEMENT: THIAZOLIDINEDIONE}

First-generation insulin-sensitizing TZDs bind directly to and activate the PPAR $\gamma$ nuclear hormone receptor [56]. The induction of PPAR $\gamma$ promotes the differentiation of large insulin-resistant pre-adipocytes into small, insulin-sensitive adipocytes [57]. This leads to an increase in FFA uptake in adipocytes, and the FFA burden is transferred to adipocytes rather than the liver [58]. TZDs have been shown to improve insulin resistance and glucose metabolism and are still used to treat T2DM.

\section{Pioglitazone}

TZD-based drugs have been reported to be effective in improving NAFLD in many human studies. In a pioglitazone trial reported in 2016 (NCT00994682), all patients $(n=101)$ with prediabetes or T2DM and biopsy-proven NASH were prescribed a low-calorie diet and then randomly assigned to pioglitazone (45 $\mathrm{mg}$ /day) or placebo for 18 months. Of the patients with pioglitazone, $58 \%$ achieved the primary outcome ( $\geq 2$ point decrease in NAS without worsening of fibrosis vs. $17 \%$ of the placebo group, $P<0.001$ ) and $51 \%$ had resolution of NASH (vs. 19\% of the placebo group, $P<0.001)$ [59].

\section{ANTIDIABETIC DRUGS FOR NAFLD MANAGEMENT: GLUCAGON-LIKE PEPTIDE 1}

Glucagon-like peptide 1 (GLP-1) analogues have been reported to be involved in weight loss and systemic insulin resistance reduction, which may lead to improvements in NAFLD. GLP-1 
Table 2. Efficacy of Antidiabetic Drugs on NASH Treatment

\begin{tabular}{|c|c|c|c|c|c|}
\hline Study author/design & Mechanism & $\begin{array}{l}\text { Intervention/ } \\
\text { control duration }\end{array}$ & Study population & Primary endpoint & Results/Other issues \\
\hline $\begin{array}{l}\text { Cusi et al. [59] } \\
\text { Phase } 4 \text { single-center, } \\
\text { randomized, } \\
\text { double-blind, } \\
\text { placebo-controlled }\end{array}$ & $\begin{array}{l}\text { Pioglitazone: } \\
\text { thiazolidinedione } \\
\text { - PPAR } \gamma \text { agonist }\end{array}$ & $\begin{array}{l}\text { 1:1 (low-calorie diet) } \\
\text { Pioglitazone } 45 \mathrm{mg} \\
\text { Placebo } \\
18 \text { months }\end{array}$ & $\begin{array}{l}\text { Biopsy-proven } \\
\text { NASH } \\
\text { (prediabetes or } \\
\text { T2DM) }\end{array}$ & $\begin{array}{l}\text { Reduction of at least } \\
2 \text { points in the } \\
\text { NAS in } 2 \text { histologic } \\
\text { categories without } \\
\text { worsening of } \\
\text { fibrosis }\end{array}$ & $\begin{array}{l}\text { Improved: } \\
58 \% \text { achieved the primary outcome } \\
\text { (treatment difference, } 41 \text { percentage } \\
\text { points) } \\
51 \% \text { had resolution of NASH } \\
\text { (treatment difference, } 32 \text { percentage } \\
\text { points) }(P<0.001 \text { for each) } \\
\text { Individual histologic scores } \\
\text { Safety: } \\
\text { Weight gain was greater with } \\
\text { pioglitazone ( } 2.5 \mathrm{~kg} \text { vs. placebo). }\end{array}$ \\
\hline
\end{tabular}

$\begin{array}{lcc}\text { LEAN trial [61] } & \text { Liraglutide: } & 1: 1 \\ \text { Phase 2 multicenter, } & \text { GLP1RA } & \text { Liraglutide 1.8 mg } \\ \text { randomized, } & & \text { Placebo } \\ \begin{array}{l}\text { double-blind, } \\ \text { placebo-controlled }\end{array} & & 12 \text { months (48 weeks) }\end{array}$

placebo-controlled
Clinical evidence of Resolution of NASH Improved:

NASH
(overweight)
without worsening of fibrosis as a pathological outcome
Resolution of NASH $(39 \%$ in the liraglutide group vs. $9 \%$ in the placebo group, relative risk $4.3, P=0.019$ ) Progression of fibrosis $(9 \%$ in the liraglutide group vs. $36 \%$ in the placebo, relative risk $0.2, P=0.04$ )
Newsome et al. [62] Semaglutide:

Phase 2 multinational, GLP1RA randomized,

double-blind, placebo-controlled

\section{$1: 1: 1: 1$}

Semaglutide $0.4 \mathrm{mg}$ Semaglutide $0.2 \mathrm{mg}$ Semaglutide $0.1 \mathrm{mg}$ Placebo 18 months (72 weeks)
Biopsy-proven NASH, F1-3 (with or without T2DM, with BMI over $25 \mathrm{~kg} / \mathrm{m}^{2}$ )
Histologic resolution Improved:

of NASH and no

worsening of fibrosis
Primary endpoint (59\% in the $0.4 \mathrm{mg}$ group vs. $17 \%$ in the placebo group, $P<0.001)$

Not improved:

Fibrosis stage

Marked/Safety:

The mean percent weight loss was $13 \%$ in the $0.4 \mathrm{mg}$ group and $1 \%$ in the placebo group.

The incidence of nausea, constipation, and vomiting was higher in the 0.4 $\mathrm{mg}$ group than in the placebo group.

\begin{tabular}{|c|c|c|c|c|c|}
\hline $\begin{array}{l}\text { D-LIFT trial [63] } \\
\text { Single-center, } \\
\text { randomized, open- } \\
\text { label, placebo-con- } \\
\text { trolled }\end{array}$ & $\begin{array}{l}\text { Dulaglutide: } \\
\text { GLP1RA }\end{array}$ & $\begin{array}{l}1: 1 \\
\text { Dulaglutide weekly } \\
0.75 \mathrm{mg} \text { for } 4 \text { weeks, } \\
\text { then } 1.5 \mathrm{mg} \text { weekly } \\
\text { Placebo } \\
6 \text { months ( } 24 \text { weeks) }\end{array}$ & $\begin{array}{l}\text { MRI-PDFF } \geq 6.0 \% \\
\text { (with T2DM) }\end{array}$ & $\begin{array}{l}\text { The difference of the } \\
\text { change in LFC } \\
\text { from } 0 \text { to } 24 \text { weeks } \\
\text { between groups }\end{array}$ & $\begin{array}{l}\text { Improved: } \\
\text { MRI-PDFF (control-corrected absolute } \\
\text { change in LFC of }-3.5 \%, P=0.025 \text {; } \\
\text { relative change of }-26.4 \%, P=0.004 \text { ) }\end{array}$ \\
\hline $\begin{array}{l}\text { EFFECTII study [67] } \\
\text { Phase } 2 \text { randomized, } \\
\text { double-blind, } \\
\text { placebo-controlled }\end{array}$ & $\begin{array}{l}\text { Dapagliflozin: } \\
\text { SGLT2i }\end{array}$ & $\begin{array}{l}\text { 1:1:1:1 } \\
\text { Dapagliflozin } 10 \mathrm{mg} \\
\quad 4 \mathrm{~g} \text { omega-3 }(\mathrm{n}-3) \\
\text { carboxylic acids } \\
\text { Combination of both } \\
3 \text { months (12 weeks) } \\
\text { Placebo }\end{array}$ & $\begin{array}{l}\text { MRI-PDFF }>5.5 \% \\
\text { (with T2DM, aged } \\
40-75 \text { years, BMI } \\
25-40 \mathrm{~kg} / \mathrm{m}^{2} \text { ) }\end{array}$ & $\begin{array}{l}\text { The change in liver } \\
\text { fat measured by } \\
\text { MRI-PDFF }\end{array}$ & $\begin{array}{l}\text { Improved: } \\
\text { Only the combination treatment } \\
\text { significantly reduced LFC (MRI- } \\
\text { PDFF ( } P=0.046) \text { and total liver fat } \\
\text { volume (relative change, }-24 \% \text {, } \\
P=0.037 \text { ) }\end{array}$ \\
\hline $\begin{array}{l}\text { E-LIFT trial [69] } \\
\text { Single-center, } \\
\text { randomized, } \\
\text { open-label }\end{array}$ & $\begin{array}{l}\text { Empagliflozin: } \\
\text { SGLT2i }\end{array}$ & $\begin{array}{l}\text { 1:1 } \\
\text { Empagliflozin } 10 \mathrm{mg} \\
\text { Standard diabetes } \\
\text { treatment without } \\
\text { empagliflozin } \\
5 \text { months ( } 20 \text { weeks })\end{array}$ & $\begin{array}{l}\text { MRI-PDFF }>6 \% \\
\text { (with T2DM) }\end{array}$ & $\begin{array}{l}\text { The change in liver } \\
\text { fat measured by } \\
\text { MRI-PDFF }\end{array}$ & $\begin{array}{l}\text { Improved: } \\
\text { Reducing liver fat (MRI-PDFF } \\
\text { difference between groups }-4.0 \% \text {, } \\
P<0.0001 \text { ) }\end{array}$ \\
\hline
\end{tabular}

(Continued to the next page) 


\begin{tabular}{|c|c|c|c|c|c|}
\hline Study author/design & Mechanism & $\begin{array}{l}\text { Intervention/ } \\
\text { control duration }\end{array}$ & Study population & Primary endpoint & Results/Other issues \\
\hline $\begin{array}{l}\text { Kahl et al. [70] } \\
\text { Phase } 4 \text { randomized, } \\
\text { double-blind, } \\
\text { placebo-controlled }\end{array}$ & $\begin{array}{l}\text { Empagliflozin: } \\
\text { SGLT2i }\end{array}$ & $\begin{array}{l}1: 1 \\
\text { Empagliflozin } \\
25 \mathrm{mg} \\
\text { Placebo } \\
6 \text { months ( } 24 \text { weeks) }\end{array}$ & $\begin{array}{l}\text { Type } 2 \text { diabetes } \\
\left(\mathrm{BMI}<45 \mathrm{~kg} / \mathrm{m}^{2},\right. \\
\text { known T2DM } \\
\text { duration } \leq 7 \text { years, } \\
\text { HbA1c of } 6 \%-8 \% \text {, } \\
\text { and no previous } \\
\text { antihyperglycemic } \\
\text { treatment) }\end{array}$ & $\begin{array}{l}\text { The change in liver } \\
\text { fat measured by } \\
\text { MRS }\end{array}$ & $\begin{array}{l}\text { Improved: } \\
\text { Reducing liver fat (placebo-corrected } \\
\text { absolute change of }-1.8 \%, P=0.02 \text {; } \\
\text { and relative change in LFC of }-22 \% \text {, } \\
P=0.009 \text { ) }\end{array}$ \\
\hline $\begin{array}{l}\text { Cusi et al. [71] } \\
\text { Phase } 1 \text { multicenter, } \\
\text { randomized, } \\
\text { double-blind, } \\
\text { placebo-controlled }\end{array}$ & $\begin{array}{l}\text { Canagliflozin: } \\
\text { SGLT2i }\end{array}$ & $\begin{array}{l}1: 1 \\
\text { Canagliflozin } \\
300 \mathrm{mg} \\
\text { Placebo } \\
6 \text { months }\end{array}$ & $\begin{array}{l}\text { Inadequately } \\
\text { controlled T2DM } \\
(\mathrm{HbA} 1 \mathrm{c} \geq 7.0 \% \text { to } \\
\leq 9.5 \%)\end{array}$ & $\begin{array}{l}\text { The difference in the } \\
\text { change for } \\
\text { intrahepatic } \\
\text { triglyceride content } \\
\text { by MRS, insulin } \\
\text { sensitivity, and } \\
\text { beta-cell function }\end{array}$ & $\begin{array}{l}\text { Improved: } \\
\text { Canagliflozin significantly improved } \\
\text { hepatic insulin sensitivity } \\
\text { Not improved: } \\
\text { Only a numerically larger absolute } \\
\text { decrease in intrahepatic triglyceride } \\
\text { content ( }-4.6 \% \text { vs. placebo }-2.4 \% \text {, } \\
P=0.09)\end{array}$ \\
\hline
\end{tabular}

NASH, non-alcoholic steatohepatitis; PPAR, peroxisome proliferator activated receptor; T2DM, type 2 diabetes mellitus; NAS, nonalcoholic fatty liver disease activity score; GLP1RA, glucagon-like peptide 1 receptor agonist; BMI, body mass index; MRI-PDFF, magnetic resonance imaging proton density fat fraction; LFC, liver fat content; SGLT2i, sodium glucose co transporter 2 inhibitor; HbA1c, glycated hemoglobin; MRS, magnetic resonance spectroscopy.

analogues may also act directly on human hepatocytes to decrease de novo adipogenesis and increase fatty acid oxidation, thereby ameliorating NAFLD [60].

\section{Liraglutide}

In the LEAN phase 2 trial, the effectiveness of subcutaneous injections of liraglutide ( $1.8 \mathrm{mg} /$ day) versus placebo for 48 weeks in overweight patients with NASH was evaluated. Nine of 23 patients (39\%) who received liraglutide showed resolution of NASH without worsening of fibrosis, compared to two of 22 patients $(9 \%)$ in the placebo group $(P=0.019)$ [61].

\section{Semaglutide}

In a 72-week phase 2 trial involving patients with biopsy-proven NASH and fibrosis (F1-F3, NCT02970942), 320 patients were randomly assigned, in a 3:3:3:1:1:1 ratio, to receive oncedaily subcutaneous semaglutide at a dose of $0.1,0.2$, or $0.4 \mathrm{mg}$ or the corresponding placebo. The primary endpoint (resolution of NASH with no worsening of fibrosis) was achieved in $40 \%$ of the $0.1 \mathrm{mg}$ group, $36 \%$ of the $0.2 \mathrm{mg}$ group, $59 \%$ of the 0.4 mg group, and $17 \%$ of the placebo group $(P<0.001$ for semaglutide [0.4 mg] vs. placebo). However, significant betweengroup differences in the improvement of the fibrosis stage were not observed. The mean percent weight loss was $13 \%$ in the 0.4 mg group ( $1 \%$ in the placebo group) [62].

\section{Dulaglutide}

Data regarding the effect of dulaglutide, a once-weekly GLP-1R agonist, on NAFLD are limited. The D-LIFT trial was a 24 week, open-label, randomized controlled trial (NCT03590626) conducted in India to determine the effect of dulaglutide $(0.75$ $\mathrm{mg}$ weekly for 4 weeks, followed by $1.5 \mathrm{mg}$ weekly for 20 weeks) on liver fat in 64 patients who had T2DM with MRIPDFF $\geq 6.0 \%$. Dulaglutide treatment led to significant reductions in LFC, with a control-corrected absolute change in MRIPDFF of $-3.5 \%(P=0.025)$ and a relative change of $-26.4 \%$ $(P=0.004)[63]$.

\section{ANTIDIABETIC DRUGS FOR NAFLD MANAGEMENT: SODIUM-GLUCOSE COTRANSPORTER 2 INHIBITOR}

Sodium-glucose cotransporter 2 inhibitors (SGLT2i) are increasingly used antidiabetic drugs that increase urinary glucose excretion by inhibiting the reabsorption of glucose in the proximal tubule of the kidney [64]. Inhibition of SGLT2 causes an additional 60 to $80 \mathrm{~g}$ of glucose per day to be excreted out of the body [65], which leads to caloric loss and weight reduction [66]. There is a growing expectation that this mechanism of SGLT2 $\mathrm{i}$ will assist in the improvement of NAFLD. 


\section{Dapagliflozin}

In the EFFECTII study (NCT02279407), which aimed to investigate the effects of dapagliflozin and omega-3 (n-3) carboxylic acids, 84 participants with T2DM and NAFLD were randomly assigned $1: 1: 1: 1$ to receive $10 \mathrm{mg}$ of dapagliflozin, $4 \mathrm{~g}$ of omega-3 (n-3) carboxylic acids, a combination of both, or placebo. After 12 weeks, only the combination treatment significantly reduced LFC as determined by MRI-PDFF $(P=0.046)$ and total liver fat volume (relative change $-24 \%, P=0.037$ ) in comparison with placebo [67]. In 32 obese patients with T2DM, 8 weeks of treatment with dapagliflozin significantly reduced LFC as determined by MRI-PDFF (placebo-corrected decrease $-3.74 \%, P<0.01)[68]$.

\section{Empagliflozin}

In the E-LIFT trial (50 patients with T2DM and NAFLD defined by MRI-PDFF >6\%), $10 \mathrm{mg}$ of empagliflozin led to a significant reduction in liver fat at 20 weeks (MRI-PDFF difference between groups $-4.0 \%, P<0.001)$ [69]. In another randomized, double-blind, phase 4 trial with T2DM patients $(n=$ $84), 25 \mathrm{mg}$ of empagliflozin treatment resulted in a placebo-corrected absolute change of $-1.8 \%(P=0.02)$ in LFC as determined by MRS and a relative change of $-22 \%(P=0.009)$ at 24 weeks [70].

\section{Canagliflozin}

In a double-blind, 24-week trial in 56 subjects with inadequately controlled T2DM (NCT02009488), changes in intrahepatic triglyceride content (IHTG) measured by MRS, insulin sensitivity, and beta-cell function were compared after treatment with canagliflozin $(300 \mathrm{mg})$ or placebo for 6 months [71]. Although canagliflozin significantly improved hepatic insulin sensitivity, only a numerically larger absolute decrease in IHTG was observed $(-4.6 \%$ vs. placebo $-2.4 \%, P=0.09)$. In patients with NAFLD $(n=37)$, the decrease in IHTG was $-6.9 \%$ vs. $-3.8 \%(P=0.05)$.

In summary, SGLT2 $i$ agents have the potential to improve NAFLD with their specific effect on weight reduction; however, the evidence for histological improvement and benefits in NAFLD patients without T2DM remains unclear.

\section{COMBINATION APPROACHES}

Since NAFLD results from multiple cellular and molecular disturbances occurring in multiple organ systems, efforts to increase the therapeutic effect by simultaneously targeting multiple mechanisms rather than a single mechanism have been pro- posed [72]. There are clinical studies with combinations of new drugs [73], and a number of clinical studies on GLP-1 based dual or triple agonists are in progress [74].

\section{Tirzepatide}

Tirzepatide, a dual agonist of the gastric inhibitory polypeptide (GIP) receptor and GLP-1 receptor, has been shown to lead to significant reductions in body weight and improvement of glycemic control in patients with T2DM [75-77]. Based on these studies, a study to confirm the therapeutic potential for non-cirrhotic NASH patients is in progress (A Study of Tirzepatide (LY3298176) in Participants With Nonalcoholic Steatohepatitis [SYNERGY-NASH], NCT04166773). This phase 2 trial comparing the efficacy and safety of tirzepatide versus placebo in patients with NASH and fibrosis (F2-F3) is recruiting participants with study completion planned for 2023. The primary endpoint is the percentage of participants with the absence of NASH and no worsening of fibrosis on liver histology at week $52[78]$.

\section{Cotadutide}

Cotadutide, a dual GLP-1 and glucagon receptor agonist, is also under development for NASH treatment. In a recent trial, cotadutide treatment for 54 weeks improved glycemic control and weight loss in patients with overweight/obesity and T2DM [79]. Thus, cotadutide can be a promising therapeutic option for the treatment of NASH via modulating mitochondrial function and lipogenesis [80]. A recent phase 2 trial was conducted to evaluate the safety (including hepatic safety), tolerability and pharmacodynamic effects in 74 participants with biopsy-confirmed NAFLD/NASH with fibrosis (F1-F3) (NCT04019561, completed/not published) [81].

\section{CONCLUSIONS}

We reviewed recent clinical trial data of newly developed drugs for NASH treatment and reports of the efficacy of antidiabetic drugs on NASH or NAFLD. Although we should wait for final results of many ongoing clinical trials, the recent failure of NASH trials strongly suggests that simply targeting one pathway or mechanism is not sufficient to ameliorate NASH. This underscores the need to find the common root of NASH progression and candidates that can modulate multiple pathways or disease cascades in NASH pathophysiology [74]. In that respect, emerging multi-target therapies or combinations of antidiabetic agents with proven clinical efficacy and safety may 
also be promising options for the treatment of NASH, and more clinical investigations should be conducted in the future.

\section{CONFLICTS OF INTEREST}

No potential conflict of interest relevant to this article was reported.

\section{ACKNOWLEDGMENTS}

This work was supported by a research grant from the Inha University to Yongin Cho and Basic Science Research Program through the National Research Foundation of Korea (NRF) funded by the Ministry of Education (2018R1D1A1B07050005) and the Korea Health Technology R\&D Project through the Korea Health Industry Development Institute (KHIDI), funded by the Ministry of Health \& Welfare, Republic of Korea (HI14C1324, HR18C0012020019) to Yong-ho Lee.

\section{ORCID}

Yongin Cho https://orcid.org/0000-0002-4645-816X

Yong-ho Lee https://orcid.org/0000-0002-6219-4942

\section{REFERENCES}

1. Gastaldelli A, Cusi K. From NASH to diabetes and from diabetes to NASH: mechanisms and treatment options. JHEP Rep 2019;1:312-28.

2. Tilg H, Moschen AR, Roden M. NAFLD and diabetes mellitus. Nat Rev Gastroenterol Hepatol 2017;14:32-42.

3. Lee YH, Cho Y, Lee BW, Park CY, Lee DH, Cha BS, et al. Nonalcoholic fatty liver disease in diabetes. Part I: epidemiology and diagnosis. Diabetes Metab J 2019;43:31-45.

4. Younossi Z, Tacke F, Arrese M, Chander Sharma B, Mostafa I, Bugianesi E, et al. Global perspectives on nonalcoholic fatty liver disease and nonalcoholic steatohepatitis. Hepatology 2019;69:2672-82.

5. Han E, Lee YH. Non-alcoholic fatty liver disease: the emerging burden in cardiometabolic and renal diseases. Diabetes Metab J 2017;41:430-7.

6. Leoni S, Tovoli F, Napoli L, Serio I, Ferri S, Bolondi L. Current guidelines for the management of non-alcoholic fatty liver disease: a systematic review with comparative analysis. World J Gastroenterol 2018;24:3361-73.

7. Sanyal AJ, Chalasani N, Kowdley KV, McCullough A,
Diehl AM, Bass NM, et al. Pioglitazone, vitamin E, or placebo for nonalcoholic steatohepatitis. N Engl J Med 2010; 362:1675-85.

8. Miller ER 3rd, Pastor-Barriuso R, Dalal D, Riemersma RA, Appel LJ, Guallar E. Meta-analysis: high-dosage vitamin E supplementation may increase all-cause mortality. Ann Intern Med 2005;142:37-46.

9. Ali AH, Carey EJ, Lindor KD. Recent advances in the development of farnesoid $\mathrm{X}$ receptor agonists. Ann Transl Med 2015;3:5.

10. Carr RM, Reid AE. FXR agonists as therapeutic agents for non-alcoholic fatty liver disease. Curr Atheroscler Rep 2015; 17:500.

11. Fiorucci S, Rizzo G, Antonelli E, Renga B, Mencarelli A, Riccardi L, et al. A farnesoid x receptor-small heterodimer partner regulatory cascade modulates tissue metalloproteinase inhibitor-1 and matrix metalloprotease expression in hepatic stellate cells and promotes resolution of liver fibrosis. J Pharmacol Exp Ther 2005;314:584-95.

12. Younossi ZM, Ratziu V, Loomba R, Rinella M, Anstee QM, Goodman Z, et al. Obeticholic acid for the treatment of nonalcoholic steatohepatitis: interim analysis from a multicentre, randomised, placebo-controlled phase 3 trial. Lancet 2019;394:2184-96.

13. Intercept Pharmaceuticals. Intercept receives complete response letter from FDA for obeticholic acid for the treatment of fibrosis due to NASH [Internet]. Los Angeles: GlobeNewswire; 2020 [cited $2022 \mathrm{Feb} 8$ ]. Available from: https://www. globenewswire.com/news-release/2020/06/29/2054576/0/en/ Intercept-Receives-Complete-Response-Letter-from-FDAfor-Obeticholic-Acid-for-the-Treatment-of-Fibrosis-Due-toNASH.html.

14. Patel K, Harrison SA, Elkhashab M, Trotter JF, Herring R, Rojter SE, et al. Cilofexor, a nonsteroidal FXR agonist, in patients with noncirrhotic NASH: a phase 2 randomized controlled trial. Hepatology 2020;72:58-71.

15. Lucas KJ, Lopez P, Lawitz EJ, Sheikh A, Aizenberg D, Hsia $\mathrm{S}$, et al. Safety and efficacy of tropifexor in patients with fibrotic nonalcoholic steatohepatitis: 48-week results from part $\mathrm{C}$ of the phase 2 flight-FXR study. Hepatology 2020; 72(Suppl 1):101A-2A.

16. ENANTA Pharmaceuticals. ENANTA announces positive results of ARGON-1 study of its lead FXR agonist, EDP305 , for the treatment of NASH [Internet]. Watertown: ENANTA Pharmaceuticals; 2019 [cited 2022 Feb 8]. Available from: https://www.enanta.com/investors/news-releases/

Copyright (C) 2022 Korean Endocrine Society 
press-release/2019/Enanta-Announces-Positive-Results-ofARGON-1-Study-of-its-lead-FXR-Agonist-EDP-305-forthe-Treatment-of-NASH/default.aspx.

17. Metacrine. Metacrine demonstrates best-in-class FXR drug program with positive clinical results in NASH patients [Internet]. San Diego: Metacrine; 2020 [cited 2022 Feb 8]. Available from: https://www.metacrine.com/metacrinedemonstrates-best-in-class-fxr-drug-program-with-positiveclinical-results-in-nash-patients/.

18. Ratziu V, Rinella ME, Neuschwander-Tetri BA, Lawitz E, Denham D, Kayali Z, et al. EDP-305 in patients with NASH: a phase II double-blind placebo-controlled dose-ranging study. J Hepatol 2022;76:506-17.

19. Sinha RA, Bruinstroop E, Singh BK, Yen PM. Nonalcoholic fatty liver disease and hypercholesterolemia: roles of thyroid hormones, metabolites, and agonists. Thyroid 2019;29: 1173-91.

20. Loomba R, Neutel J, Mohseni R, Bernard D, Severance R, Dao M, et al. LBP-20-VK2809, a novel liver-directed thyroid receptor beta agonist, significantly reduces liver fat with both low and high doses in patients with non-alcoholic fatty liver disease: a phase 2 randomized, placebo-controlled trial. J Hepatol 2019;70:e150-1.

21. Harrison SA, Bashir MR, Guy CD, Zhou R, Moylan CA, Frias JP, et al. Resmetirom (MGL-3196) for the treatment of non-alcoholic steatohepatitis: a multicentre, randomised, double-blind, placebo-controlled, phase 2 trial. Lancet 2019; 394:2012-24.

22. ClinicalTrials.gov. A Phase 3 Study to Evaluate the Efficacy and Safety of MGL-3196 (Resmetirom) in Patients With NASH and Fibrosis (MAESTRO-NASH) [Internet]. Bethesda: NIH; 2021 [cited 2022 Feb 8]. Available from: https://clinicaltrials.gov/ct2/show/NCT03900429.

23. ClinicalTrials.gov. A Phase 3 Study to Evaluate the Safety and Biomarkers of Resmetirom (MGL-3196) in Non Alcoholic Fatty Liver Disease (NAFLD) Patients (MAESTRONAFLD1) [Internet]. Bethesda: NIH; 2020 [cited 2022 Feb 8]. Available from: https://clinicaltrials.gov/ct2/show/ NCT04197479.

24. ClinicalTrials.gov. A Phase 3 Study to Evaluate Safety and Biomarkers of Resmetirom (MGL-3196) in Patients With Non-alcoholic Fatty Liver Disease (NAFLD), MAESTRONAFLD-Open-Label-Extension (MAESTRO-NAFLD-OLE) [Internet]. Bethesda: NIH; 2021 [cited 2022 Feb 8]. Available from: https://clinicaltrials.gov/ct2/show/NCT04951219.

25. Safadi R, Konikoff FM, Mahamid M, Zelber-Sagi S, Halp- ern M, Gilat T, et al. The fatty acid-bile acid conjugate Aramchol reduces liver fat content in patients with nonalcoholic fatty liver disease. Clin Gastroenterol Hepatol 2014; 12:2085-91.

26. Iruarrizaga-Lejarreta $M$, Varela-Rey M, Fernandez-Ramos D, Martinez-Arranz I, Delgado TC, Simon J, et al. Role of aramchol in steatohepatitis and fibrosis in mice. Hepatol Commun 2017;1:911-27.

27. Ratziu V, Ladron-De-Guevara L, Safadi R, Poordad F, Fuster F, Flores-Figueroa J, et al. One-year results of the global phase $2 \mathrm{~b}$ randomized placebo-controlled ARREST trial of aramchol, a stearoyl CoA desaturase inhibitor, in patients with NASH. Hepatology 2018;68:1448A-9A.

28. ClinicalTrials.gov. A Clinical Study to Evaluate the Efficacy and Safety of Aramchol in Subjects With NASH (ARMOR) (ARMOR) [Internet]. Bethesda: NIH; 2021 [cited 2022 Feb 8]. Available from: https://clinicaltrials.gov/ct2/show/ NCT04104321.

29. Loomba R, Kayali Z, Noureddin M, Ruane P, Lawitz EJ, Bennett M, et al. GS-0976 reduces hepatic steatosis and fibrosis markers in patients with nonalcoholic fatty liver disease. Gastroenterology 2018;155:1463-73.

30. Grygiel-Gorniak B. Peroxisome proliferator-activated receptors and their ligands: nutritional and clinical implications: a review. Nutr J 2014;13:17.

31. Chen J, Montagner A, Tan NS, Wahli W. Insights into the Role of PPAR $\beta / \delta$ in NAFLD. Int J Mol Sci 2018;19:1893.

32. Ratziu V, Harrison SA, Francque S, Bedossa P, Lehert P, Serfaty L, et al. Elafibranor, an agonist of the peroxisome proliferator-activated receptor- $\alpha$ and $-\delta$, induces resolution of nonalcoholic steatohepatitis without fibrosis worsening. Gastroenterology 2016;150:1147-59.

33. Harrison SA, Ratzlu V, Bedossa P, Dufour JF, Kruger F, Schattenberg JM, et al. RESOLVE-IT ${ }^{\circledR}$ phase 3 trial of elafibranor in NASH: final results of the week 72 interim surrogate efficacy analysis. In: The Liver Meeting Digital Experience 2020 of American Association for the Study of Liver Diseases; 2020 Nov 11-16; Online. Available from: https://www.natap.org/2020/AASLD/AASLD_162.htm.

34. Gawrieh S, Noureddin M, Loo N, Mohseni R, Awasty V, Cusi K, et al. Saroglitazar, a PPAR- $\alpha / \gamma$ agonist, for treatment of NAFLD: a randomized controlled double-blind phase 2 trial. Hepatology 2021;74:1809-24.

35. Francque SM, Bedossa P, Ratziu V, Anstee QM, Bugianesi E, Sanyal AJ, et al. A randomized, controlled trial of the panPPAR agonist lanifibranor in NASH. N Engl J Med 2021; 
$385: 1547-58$.

36. Junker A, Kokornaczyk AK, Strunz AK, Wunsch B. Selective and dual targeting of CCR2 and CCR5 receptors: a current overview. Chemokines 2015;14:187-241.

37. Guirguis E, Grace Y, Bolson A, DellaVecchia MJ, Ruble M. Emerging therapies for the treatment of nonalcoholic steatohepatitis: a systematic review. Pharmacotherapy 2021;41: 315-28.

38. Friedman SL, Ratziu V, Harrison SA, Abdelmalek MF, Aithal GP, Caballeria J, et al. A randomized, placebo-controlled trial of cenicriviroc for treatment of nonalcoholic steatohepatitis with fibrosis. Hepatology 2018;67:1754-67.

39. ClinicalTrials.gov. AURORA: Phase 3 Study for the Efficacy and Safety of CVC for the Treatment of Liver Fibrosis in Adults With NASH [Internet]. Bethesda: NIH; 2021 [cited 2022 Feb 8]. Available from: https://clinicaltrials.gov/ct2/ show/NCT03028740.

40. Harrison SA, Alkhouri N, Davison BA, Sanyal A, Edwards C, Colca JR, et al. Insulin sensitizer MSDC-0602K in nonalcoholic steatohepatitis: a randomized, double-blind, placebo-controlled phase IIb study. J Hepatol 2020;72:613-26.

41. Traber PG, Chou H, Zomer E, Hong F, Klyosov A, Fiel MI, et al. Regression of fibrosis and reversal of cirrhosis in rats by galectin inhibitors in thioacetamide-induced liver disease. PLoS One 2013;8:e75361.

42. Harrison SA, Marri SR, Chalasani N, Kohli R, Aronstein W, Thompson GA, et al. Randomised clinical study: GRMD-02, a galectin-3 inhibitor, vs. placebo in patients having non-alcoholic steatohepatitis with advanced fibrosis. Aliment Pharmacol Ther 2016;44:1183-98.

43. Chalasani N, Abdelmalek MF, Garcia-Tsao G, Vuppalanchi R, Alkhouri N, Rinella M, et al. Effects of belapectin, an inhibitor of galectin-3, in patients with nonalcoholic steatohepatitis with cirrhosis and portal hypertension. Gastroenterology 2020;158:1334-45.

44. Harrison SA, Goodman Z, Jabbar A, Vemulapalli R, Younes $\mathrm{ZH}$, Freilich B, et al. A randomized, placebo-controlled trial of emricasan in patients with NASH and F1-F3 fibrosis. J Hepatol 2020;72:816-27.

45. Degirolamo C, Sabba C, Moschetta A. Therapeutic potential of the endocrine fibroblast growth factors FGF19, FGF21 and FGF23. Nat Rev Drug Discov 2016;15:51-69.

46. Harrison SA, Neff G, Guy CD, Bashir MR, Paredes AH, Frias JP, et al. Efficacy and safety of aldafermin, an engineered FGF19 analog, in a randomized, double-blind, placebo-controlled trial of patients with nonalcoholic steatohepa- titis. Gastroenterology 2021;160:219-31.

47. NGM Bio. NGM Bio Reports Topline Results from 24-Week Phase 2b ALPINE 2/3 Study of Aldafermin in NASH [Internet]. San Francisco: NGM Biopharmaceuticals; 2021 [cited 2022 Feb 8]. Available from: https://ir.ngmbio.com/newsreleases/news-release-details/ngm-bio-reports-topline-results24-week-phase-2b-alpine-23-study.

48. Sanyal A, Charles ED, Neuschwander-Tetri BA, Loomba R, Harrison SA, Abdelmalek MF, et al. Pegbelfermin (BMS986036), a PEGylated fibroblast growth factor 21 analogue, in patients with non-alcoholic steatohepatitis: a randomised, double-blind, placebo-controlled, phase $2 \mathrm{a}$ trial. Lancet 2019;392:2705-17.

49. Harrison SA, Ruane PJ, Freilich BL, Neff G, Patil R, Behling $\mathrm{CA}$, et al. Efruxifermin in non-alcoholic steatohepatitis: a randomized, double-blind, placebo-controlled, phase $2 \mathrm{a}$ trial. Nat Med 2021;27:1262-71.

50. Adams LA, Anstee QM, Tilg H, Targher G. Non-alcoholic fatty liver disease and its relationship with cardiovascular disease and other extrahepatic diseases. Gut 2017;66:113853.

51. Eslam M, Sanyal AJ, George J; International Consensus Panel. MAFLD: a consensus-driven proposed nomenclature for metabolic associated fatty liver disease. Gastroenterology 2020;158:1999-2014.

52. Makki K, Froguel P, Wolowczuk I. Adipose tissue in obesity-related inflammation and insulin resistance: cells, cytokines, and chemokines. ISRN Inflamm 2013;2013:139239.

53. Marra F, Gastaldelli A, Svegliati Baroni G, Tell G, Tiribelli C. Molecular basis and mechanisms of progression of nonalcoholic steatohepatitis. Trends Mol Med 2008;14:72-81.

54. Softic S, Cohen DE, Kahn CR. Role of dietary fructose and hepatic de novo lipogenesis in fatty liver disease. Dig Dis Sci 2016;61:1282-93.

55. Lee BW, Lee YH, Park CY, Rhee EJ, Lee WY, Kim NH, et al. Non-alcoholic fatty liver disease in patients with type 2 diabetes mellitus: a position statement of the Fatty Liver Research Group of the Korean Diabetes Association. Diabetes Metab J 2020;44:382-401.

56. Soccio RE, Chen ER, Lazar MA. Thiazolidinediones and the promise of insulin sensitization in type 2 diabetes. Cell Metab 2014;20:573-91.

57. Wu Z, Bucher NL, Farmer SR. Induction of peroxisome proliferator-activated receptor gamma during the conversion of $3 \mathrm{~T} 3$ fibroblasts into adipocytes is mediated by $\mathrm{C} / \mathrm{EBPbe}-$ ta, C/EBPdelta, and glucocorticoids. Mol Cell Biol 1996;16: 
4128-36.

58. Raza S, Rajak S, Upadhyay A, Tewari A, Anthony Sinha R. Current treatment paradigms and emerging therapies for NAFLD/NASH. Front Biosci (Landmark Ed) 2021;26:20637.

59. Cusi K, Orsak B, Bril F, Lomonaco R, Hecht J, Ortiz-Lopez $\mathrm{C}$, et al. Long-term pioglitazone treatment for patients with nonalcoholic steatohepatitis and prediabetes or type 2 diabetes mellitus: a randomized trial. Ann Intern Med 2016;165: 305-15.

60. Gupta NA, Mells J, Dunham RM, Grakoui A, Handy J, Saxena NK, et al. Glucagon-like peptide-1 receptor is present on human hepatocytes and has a direct role in decreasing hepatic steatosis in vitro by modulating elements of the insulin signaling pathway. Hepatology 2010;51:1584-92.

61. Armstrong MJ, Gaunt P, Aithal GP, Barton D, Hull D, Parker R, et al. Liraglutide safety and efficacy in patients with non-alcoholic steatohepatitis (LEAN): a multicentre, double-blind, randomised, placebo-controlled phase 2 study. Lancet 2016;387:679-90.

62. Newsome PN, Buchholtz K, Cusi K, Linder M, Okanoue T, Ratziu V, et al. A placebo-controlled trial of subcutaneous semaglutide in nonalcoholic steatohepatitis. N Engl J Med 2021;384:1113-24.

63. Kuchay MS, Krishan S, Mishra SK, Choudhary NS, Singh MK, Wasir JS, et al. Effect of dulaglutide on liver fat in patients with type 2 diabetes and NAFLD: randomised controlled trial (D-LIFT trial). Diabetologia 2020;63:2434-45.

64. Madaan T, Akhtar M, Najmi AK. Sodium glucose CoTransporter 2 (SGLT2) inhibitors: current status and future perspective. Eur J Pharm Sci 2016;93:244-52.

65. Abdul-Ghani MA, Norton L, Defronzo RA. Role of sodiumglucose cotransporter 2 (SGLT 2) inhibitors in the treatment of type 2 diabetes. Endocr Rev 2011;32:515-31.

66. Sanchez RA, Sanabria H, de Los Santos C, Ramirez AJ. Incretins and selective renal sodium-glucose co-transporter 2 inhibitors in hypertension and coronary heart disease. World J Diabetes 2015;6:1186-97.

67. Eriksson JW, Lundkvist P, Jansson PA, Johansson L, Kvarnstrom M, Moris L, et al. Effects of dapagliflozin and n-3 carboxylic acids on non-alcoholic fatty liver disease in people with type 2 diabetes: a double-blind randomised placebo-controlled study. Diabetologia 2018;61:1923-34.

68. Latva-Rasku A, Honka MJ, Kullberg J, Mononen N, Lehtimaki T, Saltevo J, et al. The SGLT2 inhibitor dapagliflozin reduces liver fat but does not affect tissue insulin sensitivity: a randomized, double-blind, placebo-controlled study with 8 -week treatment in type 2 diabetes patients. Diabetes Care 2019;42:931-7.

69. Kuchay MS, Krishan S, Mishra SK, Farooqui KJ, Singh MK, Wasir JS, et al. Effect of empagliflozin on liver fat in patients with type 2 diabetes and nonalcoholic fatty liver disease: a randomized controlled trial (E-LIFT Trial). Diabetes Care 2018;41:1801-8.

70. Kahl S, Gancheva S, StraBburger K, Herder C, Machann J, Katsuyama H, et al. Empagliflozin effectively lowers liver fat content in well-controlled type 2 diabetes: a randomized, double-blind, phase 4, placebo-controlled trial. Diabetes Care 2020;43:298-305.

71. Cusi K, Bril F, Barb D, Polidori D, Sha S, Ghosh A, et al. Effect of canagliflozin treatment on hepatic triglyceride content and glucose metabolism in patients with type 2 diabetes. Diabetes Obes Metab 2019;21:812-21.

72. Thiagarajan P, Aithal GP. Drug development for nonalcoholic fatty liver disease: landscape and challenges. J Clin Exp Hepatol 2019;9:515-21.

73. Loomba R, Noureddin M, Kowdley KV, Kohli A, Sheikh A, Neff $G$, et al. Combination therapies including cilofexor and firsocostat for bridging fibrosis and cirrhosis attributable to NASH. Hepatology 2021;73:625-43.

74. Vuppalanchi R, Noureddin M, Alkhouri N, Sanyal AJ. Therapeutic pipeline in nonalcoholic steatohepatitis. Nat Rev Gastroenterol Hepatol 2021;18:373-92.

75. Frias JP, Nauck MA, Van J, Benson C, Bray R, Cui X, et al. Efficacy and tolerability of tirzepatide, a dual glucose-dependent insulinotropic peptide and glucagon-like peptide-1 receptor agonist in patients with type 2 diabetes: a 12-week, randomized, double-blind, placebo-controlled study to evaluate different dose-escalation regimens. Diabetes Obes Metab 2020;22:938-46.

76. Frias JP, Davies MJ, Rosenstock J, Perez Manghi FC, Fernandez Lando L, Bergman BK, et al. Tirzepatide versus semaglutide once weekly in patients with type 2 diabetes. $\mathrm{N}$ Engl J Med 2021;385:503-15.

77. Rosenstock J, Wysham C, Frias JP, Kaneko S, Lee CJ, Fernandez Lando L, et al. Efficacy and safety of a novel dual GIP and GLP-1 receptor agonist tirzepatide in patients with type 2 diabetes (SURPASS-1): a double-blind, randomised, phase 3 trial. Lancet 2021;398:143-55.

78. ClinicalTrials.gov. A Study of Tirzepatide (LY3298176) in Participants With Nonalcoholic Steatohepatitis (NASH) (SYNERGY-NASH) [Internet]. Bethesda: NIH; 2022 [cited 
2022 Feb 8]. Available from: https://clinicaltrials.gov/ct2/ show/NCT04166773.

79. Nahra R, Wang T, Gadde KM, Oscarsson J, Stumvoll M, Jermutus L, et al. Effects of cotadutide on metabolic and hepatic parameters in adults with overweight or obesity and type 2 diabetes: a 54 -week randomized phase $2 \mathrm{~b}$ study. Diabetes Care 2021;44:1433-42.

80. Boland ML, Laker RC, Mather K, Nawrocki A, Oldham S, Boland BB, et al. Resolution of NASH and hepatic fibrosis by the GLP-1R/GcgR dual-agonist cotadutide via modulating mitochondrial function and lipogenesis. Nat Metab 2020;2:413-31.

81. ClinicalTrials.gov. A Study to Evaluate Safety and Pharmacodynamic Efficacy of 0382 in Obese Subjects With NAFLD/NASH [Internet]. Bethesda: NIH; 2021 [cited 2022 Feb 8]. Available from: https://clinicaltrials.gov/ct2/show/ NCT04019561. 